\title{
Representing Rituals in medieval Bohemia: Circuitio in the Documents of the Late 13th Century
}

\author{
Nad'a Fiedlerová / nada.stachova@email.cz \\ Katedra dějin státu a práva PrF MU \\ Jakub Razim / jakub.razim@post.cz \\ Katedra dějin státu a práva PrF MU
}

\begin{abstract}
The transformation of legal culture from oral to written, which was taking place at a different pace and with varying intensity throughout Europe starting in the twelfth century, is the subject that has been regularly neglected by the Czech historiography. Similarly, little attention has been paid to the co-existence of legal ritual and its written records in diplomatic documents. Based on the analysis of the case from the late thirteenth century, the aim is to determine the way in which ritual circuicio was represented in charters. The question is: What strategies were chosen by the new written legal culture facing the tenaciously resisting old world of rituals? To be able to address the issue, the nature of the above mentioned sources will be defined along with the reconstruction of the intertextual network which they form.
\end{abstract}

\section{Keywords}

circuitio, rituals, law, charters, Middle Ages, intertextuality, intermediality, Czech lands 


\section{Medieval Law and Rituals}

While living in modern society dotted with universities and research institutions, it might not be that obvious that the elementary ability to read and write was once the privilege of a minority, and in many places across Europe and elsewhere it remained so for centuries. The situation was gradually changing with the development of bureaucratic administration, which with the increase of more demanding tasks could not function without a written agenda. ${ }^{1}$ There are two reasons explaining why the integration of written material into everyday life was so slow. First of all, written culture was competing with the already-established culture of spoken word and collective memory, drawn from the experience and passed from generation to generation. Secondly, there were plenty of situations where memory seemed a more useful, and even a more reliable tool for storing information than documents, which could be misused and falsified. In short, people first had to get accustomed to a new way of thinking and expressing of ideas and to learn to trust the written agenda, before they started to use it more frequently. ${ }^{2}$

To understand medieval law, one needs to be aware of its alterity. Normative system of the past was built on orally passed traditions and symbolic rituals performed in public, which represented an irreplacable guarantee of "legitimacy". ${ }^{3}$ Lately, the relationship between everyday life and its fixation in writing was thoroughly discussed by Hanna Vollrath, who was influenced by works of anthropologists. ${ }^{4}$ To characterize oral legal culture, she used the so-called normative reference points (die normativen Bezugspunkte), which according to her represented the authority providing "guidance" to settling conflicts and avoiding legal uncertainty. Medieval judges did not possess a printed, systematically arranged "reservoir" of abstract rules of conduct in the form of a legal code. All they had

1 Keller, Hagen: Die Entwicklung der europäischen Schriftkultur im Spiegel der mittelalterlichen Überlieferung. Beobachtungen und Überlegungen. In: Geschichte und Geschichtsbewußtsein. Festschrift für Karl-Ernst Jeismann zum 65. Geburtstag. Ed. P. Leidinger - D. Metzler. Münster 1990, pp. 171-204; idem: Die Entfaltung der mittelalterlichen Schriftkultur im europäischen Kontext. Schriftgebrauch und Kommunikationsverhalten im gesellschaftlich-kulturellen Wandel vom 5. bis zum 13. Jahrhundert. In: Schriftkultur zwischen Donau und Adria bis zum 13. Jahrhundert. Akten der Akademie Friesach „Stadt und Kultur im Mittelalter“, Friesach (Kärnten), 11.-15. September 2002. Ed. R. Härtel. Klagenfurt 2008, pp. 15-45, here p. 33ff. At the example of England: Clanchy, Michael T.: From Memory to Written Record. England 1066-1307. Oxford 1993, esp. p. $44 \mathrm{ff}$.

2 Briggs, Charles Fairbank: Literacy, Reading and Writing in the Medieval West. Journal of Medieval History 26, 2000, pp. 397-420, here pp. 403-404.

3 For an overview with a bibliography see Dilcher, Gerhard: Mittelalterliche Rechtsgewohnheit als methodischtheoretisches Problem. In: Gewohnheitsrecht und Rechtsgewohnheiten im Mittelalter. Ed. G. Dilcher et al. Berlin 1992, pp. 21-65; Kannowski, Bernd: Rechtsbegriffe im Mittelalter: Stand der Diskussion. In: Rechtsbegriffe im Mittelalter. Ed. A. Cordes. Frankfurt am Main 2002, pp. 1-27. On medieval law and rituals in more detail Dilcher, G.: Mittelalterliches Recht und Ritual in ihrer wechselseitigen Beziehung. Frühmittelalterliche Studien 41, 2007, pp. 297-316.

4 From the major works Vollrath, Hanna: Das Mittelalter in der Typik oraler Gesellschaften. Historische Zeitschrift 233, 1981, pp. 571-594; eadem: Herrschaft und Genossenschaft im Kontext frühmittelalterlicher Rechtsbeziehungen. Historisches Jahrbuch 102, 1982, pp. 33-71; eadem: Rechtstexte in der oralen Rechtskultur des frühen Mittelalters. In: Mittelalterforschung nach der Wende 1989. Ed. M. Borgolte. München 1995, pp. 319-348. 
was a collective memory, in which they searched for specific answers to ad hoc questions. Despite being experts on law, the judges were trained neither in writing nor in Latin. Nevertheless, due to their ability to memorize and many years of practice they acquired the necessary casuistry based primarily on procedural and penalty norms. The exact dividing lines between procedural and substantive law, or questiones iuris and questiones facti, were still absent. ${ }^{5}$ Fair settlement of disputes was to be found in an inexhaustible reservoir of experience that was gradually collected and continuously adapted to the current needs. ${ }^{6}$ Compared to the modern practice, the decision used to be binding only insofar as the recipients either experienced its effects on themselves, or kept the memory of conduct of law that was in compliance with the decision. Not surprisingly, therefore, Hanna Vollrath came to believe that in those distant times written culture was still far from having a monopoly on the regulation of legal relationships. Since written material did not correspond to the palpable medieval life rhythm of remembering and forgetting, it represented a foreign element in many layers of society (Fremdkörper). It was no exception that written evidence, carefully stored in archives of Church foundations, had to be replaced by the legal power of a prevailing custom, to which the witnesses sworn. Therefore, enforcement and protection of subjective rights was in a longer perspective provided by the repeated or continuous conduct of law, not by its fixation in writing.

However, the extensive comparative analysis presented by the British historian Susan Reynolds shows that from the twelfth century Europe had gone through a large cultural and social transformation. The "unlearned" law, articulated by human speech, was replaced by the written legal system, rationalized, professionalized and inspired by Roman law. ${ }^{7}$ Unlike in Western countries, where this issue has been actively discussed, legal rituals and their reflection in literature have received marginal attention in the Czech historiography. The following essay could thus, at least partially, redeem this lack of interest. The aim of the selected case from the late thirteenth century, is to show how ritual practices, in Latin called circuicio, were represented in diplomatic material of Bohemian origin. To avoid misunderstandings, it must be pointed out that representation in this context means, besides an observable form of a ritual, also its "actualization" in the minds of contemporaries. ${ }^{8}$

The question is: What strategies were chosen by the new written legal culture facing the tenaciously resisting old world of rituals? ${ }^{9}$ To answer this question, it is essential to

5 Cf. also Cheyette, Frederic L.: Custom, Case Law, and Medieval "Constitutionalism”. A Re-Examination. Political Science Quarterly 78, 1963, pp. 362-390, here pp. 368-371.

6 Cf. also Clanchy, M. T.: Remembering the Past and the Good Old Law. History. The Journal of the Historical Association 55, 1970, pp. 165-176, here pp. 166-168, 170-172; Kroeschell, Karl A.: 'Rechtsfindung' Die mittelalterlichen Grundlagen einer modernen Vorstellung. In: Studien zum frühen und mittelalterlichen deutschen Recht. Ed. K. Kroeschell. Berlin 1995, pp. 311-334.

7 Reynolds, Susan: Kingdoms and Communities in Western Europe 900-1300. Oxford 1990, p. 39ff.

8 Wenzel, Horst: Ritual und Repräsentation. In: Die Kultur des Rituals. Inszenierungen, Praktiken, Symbole. Ed. Ch. Wulf - J. Zirfas. München 2004, pp. 91-109.

9 On this issue cf. more recently Strategies of Writing: Studies on Text and Trust in the Middle Ages: Papers from "Trust in Writing in the Middle Ages" (Utrecht, 28-29 November 2002). Ed. P. Schulte - M. Mostert - I. van Renswoude. Turnhout 2008. 
study the "dialogue" between the two forms, by which medieval law was communicated. ${ }^{10}$ The starting point of the discussion is the fact, no matter how trivial it might seem, that both speech and gestures are fleeting means of communication. Their impact is limited by the circumstances accompanying verbal and symbolic interpretation, by the circle of recipients and the efficiency of human memory. On the contrary, written word is permanent, in theory accessible to everyone and characterized by its existential independence on the author, hence the readers. ${ }^{11}$ The debate will thus be constantly touching on the phenomena, which are in literary theory called inter-mediality and inter-textuality. ${ }^{12}$ Therefore, the attention will be paid to the tension between "physical" performances full of symbolic content on the one hand, and folios of parchment covered with letters on the other. At the same time, the unavoidable task is to reconstruct mutual functional relationships between the charters allowing us to piece together a vivid picture of a ritual scenario under which the legal act took place. However, it must be remembered that our sources capture the ephemeral "spoken" and "performed" manifestation at most indirectly when translating the described reality into language signs and symbols, thus making it permanently deformed. ${ }^{13}$

Before examining the evidence, it might be useful to explain the subject of the essay, the aforementioned ritual circuitio. The fact that it was no cultural rarity, the occurrence of which would be limited only to the territory of Přemyslid Bohemia and Moravia, is quite clearly proved by historical parallels found in the Holy Roman Empire, Poland and Hungary. ${ }^{14}$ It is no coincidence that in Latin this widespread legal ritual is called "circuitio", "circuitus" or "ambitus". It consisted literally in a walking or riding around the property on horses, the activity by which land was demarked so that it could be legally disposed of. The role of the ritual act performed in the field with the participation of local inhabitants and authorities as well as royal officials in the role of witnesses was to

10 On this matter cf. Wenzel, H.: Hören und Sehen, Schrift und Bild. Kultur und Gedächtnis im Mittelalter. München 1995, p. 356ff.

11 Bäuml, Franz Heinrich: Varieties and Consequences of Medieval Literacy and Illiteracy. Speculum 55, 1980, pp. 237-265, here p. 247ff.

12 Lexikon teorie literatury a kultury. Koncepce - osobnosti - základni pojmy. Ed. A. Nünning. Brno 2006, pp. 345-346, 351-353.

13 Cf. Müller, Jan-Dirk: Writing-Speech-Image. The Competition of Signs. In: Visual Culture and the German Middle Ages. Ed. K. Starkey - H. Wenzel. New York 2005, pp. 35-52, here pp. 37-40; Müller, J.-D.: Visualität, Geste, Schrift. Zu einem neuen Untersuchungsfeld der Mediävistik. In: Mediävistische Kulturwissenschaft. Ausgewählte Studien. Ed. J.-D. Müller. Berlin 2010, pp. 253-266, here pp. 261-263.

14 For an overview with bibliography: Szabó, Péter: Ancient woodland boundaries in Europe. Journal of Historical Geography 36, 2010, pp. 205-214; Stownik starożytności stowiańskich. Encyklopedyczny zarys kultury Stowian od czasów najdawniejszych do schytku wieku XII. Tom 6 (T-W). Ed. G. Labuda. Wrocław 1977, p. 251 (entry “Ujazd”); Handwörterbuch zur deutschen Rechtsgeschichte II (Geistliche Gerichtsbarkeit - Konfiskation). Ed. Albrecht Cordes. Berlin 2012², pp. 550-552 (entry "Grenzumgang“). Among detailed studies, see e.g. Bylina, Stanisław: Drogi - granice - most. Studia o przestrzeni publicznej i sakralnej w średniowieczu. Warszawa 2012, p. 43ff.; Maliniak, Pavol: Človek a krajina Zvolenskej kotliny v stredoveku. Banská Bystrica 2009, p. 58 ff.; Myśliwski, Grzegorz: Cztowiek średniowiecza wobec czasu i przestrzeni (Mazowsze od XII do pot. XVI wieku). Warszawa 1999, p. 23ff.; Neville, Cynthia J.: Land, law, and people in medieval Scotland. Edinburgh 2010, p. 41ff. There was also a monothematic issue of Archaeologia historica (= AH) 29, 2004 published on this topic. 
convey the land tenure, the act in Czech called "újezd". Legal historians conclude that by performing circuitio one party symbolically demonstrated the soverenity of the ownership of the surrendered territory, while the other party acquired not only legal dominion over the property, but also got the opportunity to get better acquainted with its extent. From the eleventh century, most of Bohemian charters dealt with alienation of forests, fields, meadows or pasture land. Since the land was often not cultivated with scattered population, borders of circuitio were defined by creeks, hills and roads. ${ }^{15}$

\section{Emptio venditio}

One of the sources offering a unique insight into the world of ancient legal rituals is the charter, that was discovered only recently. ${ }^{16}$ The main participants are Ojiŕ of Lomnice ${ }^{17}$, the Highest Chamberlain of the Kingdom of Bohemia and Dětřich, the abbot of the Cistercian monastery in Waldsassen. In May 1287, Ojír of Lomnice decided to sell the dower of his wife Střezka to the monastery in Waldsassen. In this sense, it was a standard sale of property that can be found in many other, both earlier and later charters. ${ }^{18}$

15 Janiš, Dalibor - Šenkýřová, Jana: Hranice statků a pozemki̊ - jejich zachyceni v pisemných (právních) pramenech. AH 29, 2004, pp. 193-202, here pp. 193-194; Marková, Markéta: Vymezováni hranic a jejich značeni v př́rodě ve středověku. In: Regiony - časoprostorové průsečíky? Ed. Robert Šimůnek. Praha 2008, pp. 98-106; Boháč, Zdeněk: Újezdy a Lhoty. Příspěvek $k$ dějinám osídleni středověkých Čech. Historická geografie 12, 1974, pp. 3-25, here pp. 5-6. Further cf. Teplý, Jaroslav: Příspěvek k problematice okrsku zvaného v listinných pramenech “circuitus”. Východočeský sborník historický 6, 1997, pp. 9-32, esp. p. 26ff.; Velímský, Tomáš: Trans montes, ad fontes! (Přes hory, $k$ pramenům!). K roli újezdi̊ při středověké kolonizaci střednich a vy̌̌šich poloh na územi severozápadnich Čech. Most 1998, here p. 111ff.; Graus, František: Dějiny venkovského lidu v době predhusitské I. Dějiny venkovského lidu od 10. stol. do proni poloviny 13. stol. Praha 1953, pp. 320-321. For a recent archeological survey including bibliography Dohnal, Martin - Šída, Petr: Historické způsoby značeni pozemkových hranic a problematika tzv. mohylovitých útvarů. Archeologie ve středních Čechách 11, 2007, pp. 635-652.

16 Katalog listin a listů $k$ VII. dílu Českého diplomatáře. I. (Zpracováni diplomatického materiálu pro obdobi květen 1283 - květen 1297) (= Katalog I). Ed. D. Havel. Brno 2011, p. 112, nr. 290. The original charter is stored in the Staatsarchiv Amberg, sig. Kloster Waldsassen 349, fol. 47b-48a. When describing the case, in addition to the below mentioned documents (A-C), the essay also draws from the earlier study Stachová, Nad'a: Komunikace na pomezi hranic na přikladu právních vztahů se zahraničním prvkem. In: Státoprávní vztahy českého státu a římskoněmecké ř́̌še ve středověku a jejich důsledky pro další vývoj. Proceedings of the colloquium organized by the Department of History of State and Law of the Law Faculty of Masaryk University and The European Society for History of Law. Ed. J. Tauchen - K. Schelle. Ostrava 2012, pp. 53-63, where these charters are analyzed in a different context, when one of the parties is a foreign recipient or acquirer.

17 Palacký, František: Přehled současný nejuyššich úředniků a důstojniků. In: Dílo Františka Palackého. [Díl] 1, Vlastní životopis Palackého. Ed. J. Charvát. Praha 1941, p. 338. Ojíř of Lomnice was the Highest Chamberlain between 1284 and 1289 - cf. Katalog I, p. 33, nr. 51 and 52, p. 112, nr. 289 and 290, p. 124, nr. 323, p. 126, nr. 331, p. 290, nr. 744, where also the earlier editions or originals are mentioned. As stated in Jan, Libor: Václav II.: král na stř́brném trůnu: 1283-1305. Praha 2015, p. 389, during the reign of Wenceslas II, the Chamberlain became the representative of the land community and at the same time held a chief position at the Land court.

18 For at least basic reference, see indexes of individual volumes of the edition Codex diplomaticus et epistolaris regni Bohemiae (= CDB), or Katalog I. Law of obligations in Bohemian charters in connection with penetration of Roman law was discussed in Boháček, Miroslav: Římské právo v listinné praxi českých zemi 12. -15. 
However, for further explanation it is necessary to emphasize two facts. Firstly, that the purchaser was a foreign institution. ${ }^{19}$ And secondly, that the transfer of property required the consent of the wife of Ojír, as it was part of her dower. ${ }^{20}$ The object of the sale were two villages in the Žatec region - Přeskaky ${ }^{21}$ and Číňov ${ }^{22}$ with all outbuildings that the wife of Ojír acquired after the death of her first husband. On behalf of the abbot of the monastery in Waldsassen, the monastery agreed to pay 200 of grivnas of silver in two installments. The first 100 grivnas of silver were paid after the consent of both involved parties was declared. The monastery obliged to pay the remaining 100 grivnas of silver in the first week following the feast of St. Wenceslas, when perambulation of transferred property should be performed. Part of the arrangements in the contract was an obligation of Ojír of Lomnice and his son Smil to be liable for defects in title for a period specified by the land law. This should protect the purchaser against any potential claims of third parties. ${ }^{23}$ The legal transfer took place at the Prague Castle with the participa-

století. Sborník archivních prací (= SAP) 24, 1974, pp. 470-477 and more recently also in Štachová, N.: Law of Obligations in Light of the Bohemian Diplomatic Documents of the Thirteenth Century. Journal on European History of Law, 2, 2011, pp. 160-164.

19 The fact that the recipient or acquirer was a foreign person could under certain conditions influence the form and content of legal deeds. However, it was domestic land law which served as the deciding legal base. Cf. Štachová N.: Komunikace, p. 62.

20 The property was donated to Střezka by her first husband Chotěbor as donatio propter nuptias. Cf. Heyrovský, Leopold: Dějiny a systém soukromého práva ř́mského. Praha 19104, pp. 881-883, who states that the original institution donatio ante nuptias (donation prior to the wedding) was amended during the reign of Justinian in the sense that some exceptions were allowed. It was also possible to make a donation after the wedding, while the regulations were adjusted according to legal aspects of the dowry. It was then common that the wife transferred what she had received via donatione propter nuptias back to the husband in dotem (by dowry). Cf. also evidence from the Hungarian milieu in Hudáček, Pavol: Právne postavenie vdovy v stredovekom Uhorsku do roku 1222 a otázka venného. Historický časopis 61, 2013, p. 242 (foreign literature on this issue is given in the Notes 70 a nd 71).

21 Formerly also Přeskače, from 1950 part of the village Chbany, located $9 \mathrm{~km}$ west of Žatec (Chomutov district) - cf. Profous, Antonín: Místni jména v Čechách. Jejich vznik, pưvodní význam a změny. Díl III (M-̌̌). Praha 1951, p. 469. Sedláček, August: Mistopisný slovnik historický Královstvi českého. Praha 1998, pp. 306307 includes a reference only to Chbany, not to Přeskaky. Chbany, located 7,5 km west of Žatec (Chomutov district), are mentioned as part of the property of the monastery in Waldsassen in Profous, A.: Mistni jména v Čechách. Jejich vznik, pưvodni význam a změny. Díl I (A-H). Praha 1947, pp. 7-8.

22 Formerly also Čínov, Čenov, Čáňov, part of the village Nové Sedlo, located 6,5 km northwest of Žatec (Louny district) - cf. Profous, A.: Místni jména. Dil I (A-H), Praha 1947, pp. 311-312. Sedláček, A.: Místopisny slovnik, p. 109 states, that this village was the residence of Mladota of Čenov from 1276. Cf. CDB V-2. Edd. J. Šebánek -S. Dušková. Pragae 1981, p. 515, nr. 819 and p. 530, nr. 828.

23 In old Czech, this institute of protection of the purchaser against claims of third parties was called "správa”. Cf. Brandl, Vincenc: Glossarium illustrans bohemico-moravicae historiae fontes. Brünn 1876, p. 387, in more detail Stieber, Miloslav: K vývoji správy. Vliv českých živli̊ na správu v Dolních a Horních Rakousích a jeji význam pro rakouský exekučni proces. Praha 1901. Roman law contains important references to the so-called eviction, i.e. recovery of an object of the sale from the purchaser by the third party - cf. e.g. Zimmermann, Reinhard: The Law of Obligations. Roman Foundations of the Civilian Tradition. Cape Town 1992, p. 293ff.; Birks, Peter: The Roman Law of Obligations. Oxford 2016, p. 81; Kaser, Max: Das römische Privatrecht 1. Das altrömische, das vorklassiche und klassische Recht. München 19712, p. 553ff.; Kaser, M.: Das römische Privatrecht 2. Die nachklassischen Entwicklungen. München $1975^{2}$, p. 390ff. From the Czech authors, see Boháček, M.: Ǩimské právo, p. 473 and in detail Vančura, Josef: Kritické poznámky k nauce o evikci př̀ řmském trhu. Sborník věd právních a státních 22, 1922, pp. 120-165. 
tion of the Bohemian King Wenceslas II. and a number of witnesses. The described case could be further simplified for better illustration. Taking into account conditions of the contract, the resulting scheme would look like this:

1. Subjects of the contract are Ojír of Lomnice as a seller and the abbot Dětřich as a purchaser.

2. Objects of sale are the villages Přeskaky and Číňov, including all outbuildings, representing the dower of Střezka, the wife of Ojír.

3. Both parties reached an agreement on the purchase price of the property, which was set at 200 grivnas of silver.

4. Both parties also agreed that the purchase price will be paid in two installments. The second installment should be paid after perambulation was performed by the seller.

5. As will be discussed later, this perambulation represented a constitutive element of the legal transfer.

6. In addition to this, the seller assumed the liability for defects in title for a stated period of time.

7. The purchase contract was made at the Prague Castle.

8. The legal transfer took place before Wenceslas II, royal officials and other witnesses.

Juristic scheme that we have just outlined, formally characterizes terms and conditions of the purchase contract. ${ }^{24}$ At first glance it may seem unfamiliar to premodern times. However, if we look closer at the individual charters documenting this case, we can see that they are formulated in the context of a newly establishing legal culture. This culture based on the learned law also affected the Czech lands during the thirteenth century. ${ }^{25}$ Its representatives already used the Roman law terminology and rational legal thinking, ${ }^{26}$ as the tools of a newly establishing intertextual and institutional network. However, it must be mentioned, that at the end of the thirteenth century this network was at the stage of a gradual formation. In otherwise oral society, the dominant position was still held by a variety of rituals, reflecting the widely respected customary practice. Legal rituals included also the aforementioned perambulation. Its legal nature will be studied on the collection of documents related to the case of Ojír of Lomnice. ${ }^{27}$

24 This corresponds to the current legal regulation of purchase contract in the Czech Republic - cf. e.g. Švestka, Jiří - Dvořák, Jan - Fiala, Josef et al.: Občanský zákonik: komentář. Sv. V (§ 1721-2520). Praha 2014, pp. 721-740.

25 Cf. Vaněček, Václav: Pronikání řimského a kanonického práva na územi dnešního Československa od 2. pol. 9. století do 1. pol. 14. století. Právněhistorické studie 12, 1966, pp. 29-36; Kejǔ, Jiř́i: Práuni kultura céského středověku. Minulostí Západočeského kraje 31, 1996, p. 12; Kejř, J.: Pronikáni kanonického práva do českého státu ve středověku. Revue církevního práva 3, 1997, pp. 139-140.

26 On this matter cf. especially Boháček, M.: Řimské právo, pp. 463-464; idem: Das römische Recht in der Praxis der Kirchengerichte der böhmischen Länder im XIII. Jahrhundert. Studia Gratiana 11, 1967, pp. 275-304; idem: Einflüsse des römischen Rechts in Böhmen und Mähren. Mediolani 1975 and idem: Řimské právo v právním vývoji českých zemí. In: Antika a česká kultura. Praha 1978, pp. 188-204.

27 For a solely formal aspect of perambulation, i.e. especially the way of demarcation and description of borders, see Janiš, D. - Šenkýřová, J.: Hranice statků a pozemki̊, pp. 193-201; transformation of villages in the Czech lands in a broader context in Klápště, Jan: Proměna českých zemi ve středověku. Praha 2012², pp. 223-226. 


\section{Circuitio}

The following part of the essay will examine how the purchase and sale were negotiated between the Highest Chamberlain Ojír and the Bavarian monastery in Waldsassen. When reconstructing the inter-textual and inter-media networks influencing the transaction, the focus will be first on separate links, namely the individual sources from the late thirteenth century. Then, the relationships between these links and how they affected the representation of circuitio will be discussed.

The first example is the charter preserved only as a copy. It is called charter A. ${ }^{28}$ This document provides undoubtedly the biggest amount of information on how the sale was conducted between the Bohemian nobleman and the monastery in Waldsassen. It was initiated and sealed by Ojíř of Lomnice. The closest relatives of Ojír, his wife Střezka and his son Smil, also attached their seals. The charter explicitly refers to the Register of Prague beneficiaries, which represents the Land tables, to which there are only sporadic references from the thirteenth century. ${ }^{29}$ Into these Land tables were recorded not only the approval of the wife of Ojír with the sale of the two villages, but also his authorization to a free disposal thereof (de libero et expresso consensu nec non speciali mandato eiusdem coniugis nostre, prout in registro beneficiariorum Pragensium, coram quiubus eadem coniunx nostra consensum expressit huiusmodi ac mandatum, evidenter apparet). ${ }^{30}$ The charter of Ojír is thus considered one of those rare documents proving indirectly the existence of the Land tables, in the late thirteenth century.

The charter of Ojír as the first link of the intertextual network, is followed by a document which is called charter B. ${ }^{31}$ It was drawn by the scribe of the Land court in Prague, who managed to summarize the fundamental conditions of the sale by using several precise juristic terms. Although it is a relatively brief document, charter B specifies some aspects of the charter of Ojír of Lomnice. For example, the passage mentioning the liability for defects in title, to which both the seller and his son Smil obliged themselves. ${ }^{32}$

28 Staatsarchiv Amberg, sig. Kloster Waldsassen 349, fol. 47b-48a. Katalog I, nr. 290, p. 112.

29 For the origin of the Land tables, see Randa, Antonín: Přehled vzniku a vývinu desk čili knih veřejných, hlavně $v$ Čechách a na Moravě. Praha 1870; Redlich, Oswald: Die älteste Nachrichten über die Prager Stadtbücher und die böhmische Landtafel. Mitteilungen des Instituts für Österreichische Geschichtsforschung (= MIÖG) 32, 1911, pp. 165-171; Vojtíšek, Václav: K počátkům městských knih pražských a desk zemských. In: V. Vojtíšek. Výbor rozprav a studií. Praha 1953, pp. 229-239; Fiala, Zdeněk: Panounické listiny, kancelář a zemský soud za Přmysla II. (1247-1253-1278). SAP 1, 1951, pp. 165-288; the situation especially after 1541 accentuated in Burdová, Pavla: Uloženi desek zemských od založeni do přitomnosti a jejich ochrana a konzervace. SAP 24, 1974, pp. 487-510; eadem: Desky zemské: ukázky a rozbor vkladů nejstaršich desek. Praha 1984 (further literature in pp. 8-9); eadem: Úŕad desek zemských. SAP 36, 1986, pp. 273-381; eadem: Desky zemské Králouství českého. Praha 1990; eadem: Vývoj intabulací desek zemských. Paginae historiae: sborník Státního ústředního archivu v Praze 1992, pp. 7-22. For the situation in Moravia, see Janiš, D.: Úvahy nad počátky zemských desk na Moravě. In: Nový Mars moravicus aneb sborník příspěvků, jež věnovali Prof. Dr. Josefu Válkovi jeho žáci a přátelé k sedmdesátinám. Ed by B. Chocholáč - L. Jan - T. Knoz. Brno 1999, pp. 243-250.

30 Staatsarchiv Amberg, sig. Kloster Waldsassen 349, fol. 47b.

31 Regesta diplomatica nec non epistolaria Bohemiae et Moraviae (= RBM) II. Ed. J. Emler. Pragae 1882, pp. 605-606, č. 1409. Katalog I, p. 112, nr. 289.

32 RBM II, p. 605, č. 1409. Land law required that the liability for legal defects of transferred property lasted 
Charter B could be described as an excerpt from the Land tables, with two passages specifically referring to these tables. The first is the scribe's reference to a more detailed record in the register of Prague beneficiaries, which is related to the approval of the wife of Ojír and the authorization that was granted to him (quia uendidit dotem vxoris sue Ztrezce ea consenciente, ut in registro plenius continetur). ${ }^{33}$ The second reference is at the very end of charter B where the scribe emphasizes that Ojír and the abbot of the monastery in Waldsassen ordered aloud to record everything in the Land tables (Et hec omnes ex utraque parte uiua uoce registro omnia inseri mandauerunt $)^{34}$.

The third charter contains the record of the performed perambulation, and is called charter C. ${ }^{35}$ This latter document, which is preserved only as a fragment, is completely rare in the Czech environment. It can be seen as a written evidence that the issuers of the charter - the Žatec county reeve (iudex provincialis) along with the servant (miles) of Ojír observed by order of Ojír of Lomnice all formalities required by the local custom that the possesion of the acquired villages was conveyed to a foreign purchaser. However, no similar records are available for Czech recipients. The only comparable material are three written records in the oldest register of the Prague bishopric, which in the form of short marginal notes provide a register of witnesses present at the perambulation. ${ }^{36}$ Therefore, it might seem that the creation of charter $\mathrm{C}$ must be put into context with the fact that the new purchaser of the earlier mentioned villages was a foreign church institution. At the same time, this charter can also be seen as an evidence that one of the fundamental conditions of a legal transfer was met and that the monastery wanted a written evidence of this transfer.

This record of perambulation is stylistically based neither on the charter of Ojír nor on the excerpt from the Land tables, yet it provides similar data to those present in the two mentioned charters. The scribe's hand of charter $\mathrm{C}$ has not been traced yet. According to a paleogeographic analysis, it seems that the charter was drawn in the Czech lands. ${ }^{37}$ Therefore, the question is whether the scribe of charter $\mathrm{C}$ had access to charters $\mathrm{A}$ and $\mathrm{B}$, or whether he drew information from an actual record in the Land tables. Another possibility is that the seller or authorized persons only informed him about the course of the sale process, since in order to be able to draw the charter he had to have at least basic knowledge of steps preceding the perambulation.

From the previous comments on the individual charters we can draw a partial conclusion. All three charters are connected by the same legal case. All three of them, in one way or another, describe the sale of property to the foreign monastery. The explicit

three years and eight weeks, which was a period commonly used in such cases (easdem villas a quolibet inpeditore in sive affini vel non affini per triennium secundum ius terre emendare).

33 RBM II, p. 605, nr. 1409.

34 RBM II, p. 606, nr. 1409.

35 Katalog I, p. 124, nr. 323. The fragment is now stored under the sig. Archiv Národního muzea (= ANM), Pergamenové listiny, A 37.

36 RBM II, p. 719, nr. 1674; p. 725, nr. 1687. Katalog I, p. 339, nr. 862-864. Now stored under in ANM, Pergamenové listiny, A 43, fol. 2b.

37 The authors of this essay thank doc. Dalibor Havel for the consultation on this issue. 
references in charters A and B also refer to another link of intertextuality, which are the Land tables. These references allow to reconstruct in more detail their original form and the character of records. The mutual relationships between individual links of the intertextual network in question, however, become most clear, if we manage to identify a uniform formula or rather a strategy of representation of ritual circuicio.

In charter A, ritual circuicio is presented as one of the steps required for a valid transfer of property by the date agreed on by both parties. The remaining amount of the purchase price, to which the performance of preambulation was bound, should also be paid by the same date. What is extremely interesting in this context is a postscript explaining the cause of perambulation. As we have already mentioned, the sale of property took place at the Prague Castle, where it was also recorded in the Land tables. In this situation, Ojír feared that other courts ${ }^{38}$ which were out of the domain of jurisdiction of the Land court in Prague ${ }^{39}$ may not be informed about the transfer (ut ex hoc et aliis iudiciis, quecumque per nos [i.e. Ojiř of Lomnice] fieri poterunt, clareat manifeste prefata bona ad ius et proprietatem monasterii dicti plenissime devoluta). ${ }^{40}$ For a clear evidence of the legal transfer, the properties should be perambulated at the place of location, which means in the Žatec region, and in full compliance with the local custom (mos terre). Therefore, perambulation, as a visible and traditional symbolic act, should ensure adequate publicity to the act of conveyance (clareat manifeste), not only at the local level. In addition to this, present witnesses, who could confirm that the perambulation actually occurred, provided a good guarantee that the sale, even if questioned, would remain valid.

The earlier mentioned postscript shows that at that time the Land tables served to officials as an auxiliary register. It was a new institution, which was not yet fully established. ${ }^{41}$ Therefore, records from the register of Prague beneficiaries were often con-

38 References to the existence of these courts in Jan, L.: Několik postřehů $k$ vývoji panovnické komory, soudů a správy země. In: Pocta Janu Janákovi. Předsedovi Matice moravské, profesoru Masarykovy univerzity věnují k sedmdesátinám jeho přátelé a žáci. Ed. B. Chocholáč - J. Malír. Brno 2002, pp. 79-80.

39 The discussion on the establishment of the Bohemian Land court has a long tradition in Czech historiography. Here cf. only most recent literature, including references to earlier works by R. Koss, R. Rauscher, J. Vacek, F. Palacký, J. Čelakovský, J. Teige, H. Jireček, Z. Fiala and others. Starý, Marek: Předni klenot zemský: větši zemský soud království českého v době rudolfínské. Praha 2014, esp. pp. 17-21; Jan, L.: Václav II. a struktury panounické moci. Brno 2006, pp. 194-215; idem: Zrod zemského soudu v Čechách. In: Kultura prawna v Europie Środkowej. Ed. A. Barciak. Katowice 2006, pp. 227-239; comparison with the situation in Moravia is also relevant - cf. Janiš, D.: Zemské soudnictvi na Moravě vrcholného středověku, Brno 2013 and Jan, L.: Vznik zemského soudu a správa středověké Moravy. Brno 2000; idem: Institucionalizace zemského soudu a formováni šlechtické zemské obce. In: Morava a české národní vědomí od středověku po dnešek. Sborník z konference Češi nebo Moravané? K vývoji národního vědomí na Moravě, konané dne 28. 2. 2001 v Brně. Ed. J. Malíř - R. Vlček. Brno 2001, pp. 33-40. The issue of administration of justice and the position of land law in the Middle Ages and Early Modern Period is discussed in the monograph Jan, L. -Janiš, D.: Ad iustitiam et bonum commune. Proměny zemského práva v českých zemích ve středověku a raném novověku. Brno 2010. In a wider context cf. Malý, Karel: Zemský soud ve struktuře stavovského práva a právní kultury. In: Traditio et cultus. Miscellanea historica Bohemica Miloslao Vlk archiepiscopo Pragensi ab eius collegis amicisque ad annum sexagesimum dedicata. Ed. Z. Hledíková. Praha 1993, pp. 109-117. In English Grant, Jeanne E.: For the common good. The Bohemian land law and the beginning of the Hussite Revolution. Leiden Boston 2015, p. 27ff.

40 Staatsarchiv Amberg, Kloster Waldsassen 349, fol. 47b-48a.

41 Havel, D.: Listinné písmo v českých zemích na přelomu 13. a 14. století. Brno 2008, pp. 15-17. From the earlier 
sidered of a lesser importance than later in the High Middle Ages, if they were not accompanied by symbolic acts, required by local customs, which provided and legitimized transfers of property. The principle of credibility and public trust in records in the Land tables was established gradually before other courts in Bohemia. ${ }^{42}$ The attached seals of Ojír, his wife Střezka and his son Smil served as a guarantee that the purchase made by the foreign church institution would not be threatened by anything and anybody.

Therefore, charter A implies that the charter itself was not sufficient enough for the valid transfer of property. It also counted on the fact that ritual circuicio would be performed in the near future and in accordance with the local custom (mos terre). This performance should provide what the charter itself could not ensure - visibility, clarity and physical performance at a particular place and time. A certain "lack of dependence" of charter $\mathrm{A}$ is demonstrated by the fact that it was created in the presence of many witnesses, and even in the presence of the King and relatives of Ojír, who repeatedly expressed their approval. Smil did this by attaching his seal and by making the oath before the King, that after the death of his father he will be liable for defects in title. Střezka, the wife of Ojír, did this by oral approval expressed in front of Prague officials and by attaching her seal.

The character of representation of ritual circuicio in charter B and in charter A differs. While in charter A ritual circuicio is represented as an intended and even reasoned act of Ojír, in charter B it is represented very formally in form of a simple excerpt from the Land tables as one of the requirements of the act of conveyance conditioning the payment of the rest of the purchase price. A more detailed description of the performance of ritual circuicio is not included. The scribe of the charter stated only time and place and defined what properties should be perambulated. However, he points out explicitely that ritual circuicio is the act which is in accordance with the local custom. Charter B thus represents a juristic accurate record that anticipates the performance of perambulation because it forms an essential part of the act of conveyance.

Finally, charter $\mathrm{G}$ gives the most detailed description of ritual circuicio, since it is a direct record of the performance of perambulation of the villages in question. The realization was entrusted to the Žatec county reeve Přibyslav of Žebrák ${ }^{43}$ as a representative of local authorities, and the servant of Ojír of Lomnice, who should by order of Ojír of Lomnice provide protection of the transferred villages for the period specified by the land law. ${ }^{44}$ Although charter $\mathrm{G}$ does not mention the payment of the remaining

literature Markov, Josef: Př́pravné ř́zeni procesni v českém právu zemském XIII.-XVII. stol. Bratislava 1930, esp. pp. 49-50; Markov, J.: České žalobni formuláře a reformy Přemysla II. a Karla IV. Bratislava 1936, p. 25.

Cf. Markov, J.: Kapitoly z dějin českého zemského soudního řizeni XII.-XVII. století. Praha 1967, esp. pp. 147150, 174, 255-257, 397-300.

43 For a more detailed identification, see Jan, L.: Václav II., p. 649, note 71. See also CDB V-1. Edd. J. Šebánek - S. Dušková. Pragae 1974, p. 146, nr. 91 and CDB V-2, p. 565, nr. 850.

44 Jan, L.: Václav II., p. 450 identifies these villages as Čížov and Břežany. According to the authors of this essay, the former village might be the aforementioned Číňov, the latter might be Břežany. However, the part of the original charter where the latter village is mentioned is hardly legible. The original charter states the names Preisser or just Presser, which corresponds to the German version of the name Břežany - cf. Sedláček, A.: Mistopisný slownik, p. 64 and Profous, A.: Místní jména I, p. 171. The question thus arises why 
part of the purchase price, it can be assumed that it happened before perambulation was performed. According to the date which can not be exactly determined because the relevant text is missing in the preserved fragment, it might be concluded that perambulation took place at a different time than was agreed.$^{45}$ It is possible that it could be due to a debtor's default. However, there are no detailed references regarding this.

In charter $\mathrm{C}$ it is stated that ritual circuicio took place before the local nobility, Žatec burghers and representatives of the major monasteries in Bohemia. The purchasing party was represented by monks and laymen from the monastery in Waldsassen. The intention of contractors in such situations was to mobilize local authorities and influence their legal memory, as long as it was related to the realized property transaction. ${ }^{46}$ The charter, however, lacks any further description of the ritual performance. In relation to perambulation, the scribe used two verbs: circuire and demonstrare (or demostracio), by which he describes the performative dimension of the ritual and its dynamic nature, with a purpose of demarcation of the land. On the basis of the terms used it can be assumed that ritual circuicio consisted in the fact that the transferred property was perambulated by the participants and shown to the new purchaser, therefore was sufficiently clearly demarked and distinguished from other properties. ${ }^{47}$

Besides these two verbs we can find another verb assignare (or assignacio), which refers to the part of the act of conveyance, which was associated with the transfer of possesion. As was discussed earlier, a contract as such, or an agreement between the parties was not sufficient for the transfer of property. Therefore, the actual transfer of possesion had to play an important role in the sale of property. The verb assignare is also closely related to the earlier described ritual performance. Boundaries that were usually demarked during perambulation, were in charters often referred to as signum. ${ }^{48}$ All three used terms - together and separately - show that the scribe of the charter found it important to capture the essence of the performed ritual by these terms.

At the end of charter $\mathrm{C}$ we can read that this ritual transfer of property should remain intact (Ut igitur dictarum villarum assignacio sive demonstracio inconvulsa perm[aneat] ...). ${ }^{49}$ The reality based on perambulation should last. On the other hand, the arenga of the charter emphasizes that "everything that happens, disappears in the flow of time", unless it is put in writing (Quoniam ea, que geruntur, cum lapsu temporis elabuntur, si non litterarum

the scribe of the charter C stated Břežany instead of Přeskaky. However, to clarify this issue would require a separate discussion.

45 The dating formula, which is not complete in the original charter, is as follows: Acta sunt hec anno domini M.CC.LXXXVII in die sancti Th... martiris. Most likely it is the Feast of St. Theodore the Martyr falling on November 9 - cf. Friedrich, Gustav: Rukovět krestanské chronologie. Praha 1997², p. 333.

46 Górecki, P.: Communities of Legal Memory, pp. 136, 148, 151-154.

47 Janiš, D. - Šenkýřová, J.: Hranice statků a pozemki̊, p. 193.

48 Cf. e.g. CDB I. Ed. G. Friedrich. Pragae 1904-1907, p. 421-422, nr. 403; CDB II. Ed. G. Friedrich. Pragae 1912, p. 174-175, nr. 188; CDB III-2. Edd. G. Friedrich - Z. Kristen. Pragae 1962, p. 280-283, nr. 214; CDB IV-1. Edd. J. Šebánek - S. Dušková. Pragae, 1962, p. 277-281, nr. 171++; CDB V-2, p. 193-195, nr. $599^{++}$; p. 247-260, nr. 636, 637.

49 Katalog I, p. 124, nr. 323. ANM, Pergamenové listiny, A 37. 
testimonio). ${ }^{50}$ The idea that writing should serve as a tool for memory to better resist the relentless course of time, was a popular literary topic in the Middle Ages. ${ }^{51}$ The written record of perambulation, in which the "memory" motif is reflected, clearly shows the efforts to keep ritual events from falling into oblivion. At the same time, however, it questions stability of the situation based on the legal ritual, since a documentary evidence, not legal act itself is perceived as an exclusive means of preservation of property rights pro futuro. ${ }^{52}$

\section{Representation of the Ritual}

The final part of the essay will summarize how circuicio is represented in the aforementioned charters. Charter A assumes circuicio as a future event. At the same time it makes itself dependent on this event - according to Ojír, only circuicio can clearly show the new reality regarding the remarking of boundaries and land demarked by these boundaries. In other words, the reference to circuicio in charter A refers to future performance that can not be provided by any other charter or link of intertextuality. On the other hand, after the ritual was performed, charter $\mathrm{C}$ was drawn, proving its realization. According to this charter, the ritual itself was not independent and sufficient enough. As it is a real event in time and space, it will be forgotten and will disappear in time. Charter $\mathrm{C}$ attributes to the ritual its inability to guarantee what it demonstrates and implicates. Given that both of these charters were initiated by Ojír, we can assume the unity of purpose. The new written form of legal life tries to change the old ritual-symbolic way of shaping the legal reality; it chooses what is worth recording and what is not, as is apparent particularly in charter B. It leaves out of consideration the original symbolic act in the presence of witnesses, the course of which depends on a situation, and attempts to enforce a new authoritative form of regulation of social conditions, which prefers a written form to ritual gestures and speeches.

It might seem that the ritual performance is completely "trapped" in an intertextual network, linking both the Land tables and the above discussed charters dealing with the sale of property of Ojír to the Cistercian monastery in Waldsassen. On the other hand, it is a well-known fact that most people of that period, except clerical and secular elites, were illiterate. Legal rituals thus appear as an irreplaceable social institution through which legal reality was formed in a sea of illiteracy. We must still reckon with the existence of the living law and remember that literary representation is merely a more or less distorted mirroring of its customary practice. Therefore, it would be necessary to carry out an independent research into this phenomenon at the time preceding the written culture. However, we can already say that many of the conclusions made by Susan Reynolds for the area of Western Europe, also apply to the Czech lands: There was no

50 Katalog I, p. 124, nr. 323. ANM, Pergamenové listiny, A 37.

51 Herold, Paul: Intertextualität im Kontext von Urkunden. MIÖG 112, 2004, p. 141-162, here pp. 146-150; Fichtenau, Heinrich: Arenga. Spätantike und Mittelalter im Spiegel von Urkundenformeln. Graz 1957, p. 131ff.

52 See also Wenzel, H.: Hören und Sehen, Schrift und Bild, pp. 357, 365. 
unbridgeable gap between the world of oral and written law. On the contrary, there was a symbiosis and mutual penetration between the two spheres. Therefore, the thirteenth century appears to us as a period of transformation, a smooth transition between the "old" and "new" law, whose deeper understanding can be considered a desideratum of legal history on a local and also European scale.

\section{CIRCUITO IN THE DOCUMENTS}

\section{INTERTEXTUALITY}

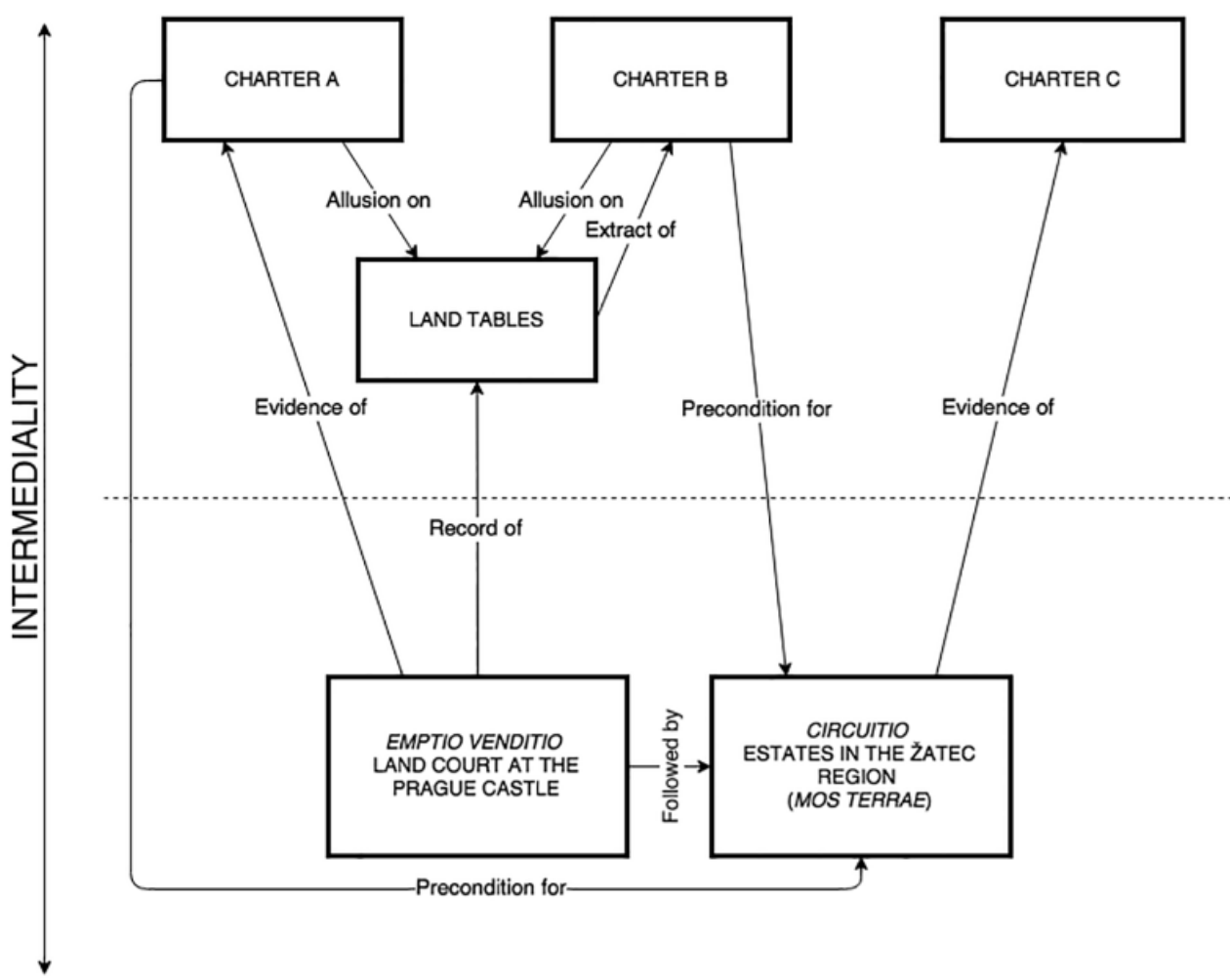




\section{Reprezentace rituálu ve středověkých Čechách: Circuitio v písemnostech pozdního 13. století}

Transformace právní kultury z mluvné na psanou, která probíhala různým tempem a s různou intenzitou po celé Evropě počínaje 12. stoletím, je tématem v české historiografii tradičně opomíjeným. Stejně malá pozornost je pak věnována i koexistenci právního rituálu a jeho písemného zachycení v diplomatickém materiálu. Na základě analýzy případu z konce 13. století jsme se pokusili určit způsob, jakým je rituál circuicio reprezentován v listinách. Klíčová otázka, kterou jsme si v příspěvku položili, zní: Jaké strategie volila nová písemná právní kultura při styku se starým světem právních rituálů? Abychom na ni mohli odpovědět, nejprve jsme na základě dochovaných pramenů ve stručnosti představili vybraný případ. Následně jsme vymezili povahu analyzovaných pramenů a rekonstruovali intertextuální sít, kterou vytvářejí. Přitom jsme se primárně zaměřili na to, jakým způsobem byl rituál circuicio jednotlivými články této intertextuální sítě reprezentován. Konečně v závěru jsme se pokusili nabídnout kritické zhodnocení identifikovaného způsobu reprezentace rituálu circuicio $\mathrm{v}$ dochovaném diplomatickém materiálu. 
